\title{
O Kwaryp kamaiurá na aldeia de Ipavu
}

\section{CARMEN JUNQUEIRA e VANESKA TACIANA VITTI}

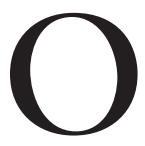

KWARYP é uma cerimônia em homenagem aos mortos, realizada pelos povos indígenas do Alto Xingu. De fato, é a etapa final de uma sequência de ritos iniciados após o falecimento de uma pessoa e marca o término do luto dos parentes. Uma de suas características marcantes é a rememoração que faz do ato primordial da criação da humanidade, obra da divindade mítica Mavutsinin.

Diz a tradição que, em tempos recuados, o Kwaryp foi realizado em Morená, terra situada na confluência dos rios Ronuro, Batovi e Culuene, local da morada de Mavutsinin. Com o intuito de povoar o mundo, Mavutsinin cortou troncos de árvore, fincou-os no chão, pintou-os e, finalmente, enfeitou-os com colares, braçadeiras de penas de arara, cocares e fios de algodão. Ao som de maracás, duas cutias entoaram cantos que se estenderam por longas horas, até que, pouco a pouco, os troncos foram ganhando forma: primeiro surgiram os braços, depois a cabeça, o tronco, pernas e, enfim, todo o corpo dos novos seres.

A criação, porém, estava incompleta. Era preciso dar a cada criatura uma identidade própria. Mavutsinin mostrou-lhes vários artefatos para que escolhessem o que mais os agradassem. Os Kamaiurá, convocados em primeiro lugar, escolheram o arco preto; os Kuikuro, o colar de lâminas de concha; os Kalapalo, o cinto de discos de caramujo; os Waurá, a panela de cerâmica; até que todos, embora semelhantes na origem, pudessem ostentar peculiaridades e diferenças. Foram distribuídos pelas cercanias, exceto o "não índio" que, portando a espingarda que escolhera, foi mandado para bem longe.

Seria então a festa do Kwaryp uma louvação à vida? Num certo sentido, sim. Bastaria entender o término do luto como sinal da retomada da existência cotidiana na aldeia, em que o pesar cede lugar à alegria do viver.

Uma outra narrativa mítica, porém, que trata do primeiro Kwaryp realizado por Mavutsinin, amplia o sentido da cerimônia. Com a intenção de devolver a vida aos mortos, Mavutsinin fincou os troncos de madeira na aldeia e os pintou e adornou. Após muitas horas de canto, ele mandou que todos se fechassem em suas casas, permanecendo apenas ele junto aos troncos que começaram então a ganhar forma humana. Quando a transformação se completou, Mavutsinin mandou que os homens saíssem das casas para saudar os renascidos, expressando alegria e felicidade. Apenas os que tivessem tido relação sexual durante a noite não deveriam deixar suas casas para participar da comemoração. Somente um 
homem permaneceu dentro da casa, mas, vencido pela curiosidade, saiu para apreciar o espetáculo. No mesmo instante os ressuscitados voltaram a ser troncos de madeira.

Mavutsinin lamentou que seu intento de dar vida aos mortos tivesse sido frustrado pela transgressão ritual e lançou uma imprecação: "De agora em diante, os mortos não conhecerão uma nova vida por ocasião da cerimônia do Kwaryp", nela serão apenas relembrados e homenageados.

Do ponto de vista etnológico, o ciclo de rituais que culmina com a realização do Kwaryp tem um significado ainda mais amplo.

A região dos formadores do Rio Xingu é conhecida por reunir povos falantes de diversas línguas (tupi, aruak, karib e a língua isolada trumai) que compartilham um estilo de vida bastante semelhante. ${ }^{1}$ Os principais eventos responsáveis pela interação entre diferentes aldeias são a cerimônia do Kwaryp, realizada em homenagem aos mortos, do Jawari, competição esportiva de arremesso de flechas, e a troca de bens denominada Moitará.

O prolongado contato entre as comunidades deve ter sido responsável pelo estabelecimento de uma vizinhança amistosa, mas também fez que os diferentes povos alimentassem pretensões de alcançar hegemonia na região. Coexistem assim entre eles tanto um relacionamento amigável como formas de comportamento que revelam competição e oposição. A maioria dos estudos etnológicos sobre a relação dos kamaiurás com povos vizinhos destaca a unidade alto-xinguana e ao mesmo tempo registra o sentimento de desconfiança e rivalidade que permeia seus vínculos (cf. Galvão, 1979a, 1979b, 1979c; Agostinho, 1974; Schaden, 1964; Oberg, 1956).

Com o objetivo de esclarecer os momentos em que tais atitudes opostas se manifestam, a intenção deste texto é descrever a cerimônia do Kwaryp, ${ }^{2}$ ocasião cerimonial única que reúne a maioria dos povos da região em uma aldeia anfitriã, e focalizar os principais procedimentos envolvidos na realização da festa, destacando as práticas voltadas tanto para reafirmar a coesão social como para expressar a ambiguidade das relações entre as diferentes aldeias. Solidariedade e hostilidade se alternam na configuração do universo alto-xinguano e revelam a complexa rede política que o envolve.

Os dados aqui apresentados foram coletados durante várias estadas na aldeia Kamaiurá: agosto e setembro de 2003, agosto de 2004, julho de 2005, 2006 e 2007, quando assistimos à realização de duas cerimônias do Kwaryp (2004 e 2007). Em agosto de 2003, acompanhamos os Kamaiurá que participaram do Kwaryp na aldeia Iawalapiti, e em julho de 2006 fomos com os Kamaiurá assistir à festa do Jawari na aldeia Waurá. Em agosto de 2006 fomos com os Kamaiurá participar do Kwaryp na aldeia Kalapalo. Além de observar os diversos rituais, registramos dados obtidos por meio de vídeo, entrevistas informais, semiestruturadas, depoimentos gravados e acompanhamos sistematicamente as relações entre anfitriões e convidados. 
O foco da nossa análise é a aldeia Kamaiurá de Ipavu. Seus moradores se distribuem em 15 imponentes casas situadas ao redor de um amplo pátio circular. Cada casa, erguida pela iniciativa de um homem que dela se torna chefe, reúne pessoas unidas por parentesco, formando uma unidade de produção econômica. Quanto maior o número de moradores, maior tende a ser o prestígio de seu chefe que pode assim contar com uma base de apoio mais ampla.

A rede de relações que organiza a vida comunitária tem como principal sustentáculo o parentesco. Grupos unidos em torno de um homem e sua prole buscam selar aliança entre si por meio do casamento, gerando um novo conjunto de parentes por afinidade, que em alguns casos se sobrepõe a laços consanguíneos. O casamento preferencial é entre primos cruzados (atywahap) (filho ou filha do irmão da mãe ou filho ou filha da irmã do pai), embora outras combinações sejam possíveis, e até desejáveis, dependendo do valor estratégico da aliança. Tal procedimento cria vínculos entre famílias da própria comunidade e também entre diferentes aldeias e povos da região dos formadores do Xingu, em especial.

Descrita dessa forma, a rede de parentesco que envolve os moradores de Ipavu não registra um aspecto importante das relações e que diz respeito à atitude de desconfiança, de suspeita e até mesmo de intolerância velada que recai sobre parentes afins. ${ }^{3}$ Assim, a necessidade de selar aliança e ter parentes em outras casas ou aldeias institui novos compromissos e deveres, mas gera simultaneamente desconfiança. Embora a etiqueta tradicional bloqueie a explicitação pública desses sentimentos, eles são amplamente revelados em círculos mais íntimos de consanguíneos. Acusações referentes à quebra dos deveres do genro em relação ao sogro, à sovinice da segunda esposa do pai, até outras mais graves como a de procedimentos mágicos de caráter negativo envolvendo genros e sogro não são incomuns. O potencial desagregador dessa animosidade é na maioria das vezes abafado pelo interesse político em preservar a aliança, que conta com uma poderosa aliada: a etiqueta que rege a conduta e formaliza as relações. Assim, a relativa serenidade da vida comunitária é fruto da contenção de sentimentos potencialmente antissociais. O Kamaiurá abdica de uma espontaneidade ingênua a favor de um desempenho diplomático ditado por interesses políticos de maior grandeza.

Tanto nos rituais e cerimônias como na rotina diária é grande a circulação de bens e serviços entre famílias, entre moradores de diferentes casas e aldeias. Circulam alimentos, objetos, convites, prestação de serviço, que, aceitos, devem ser retribuídos em algum momento futuro. A doação reforça vínculos sociais e confere prestígio ao doador, pois a generosidade é altamente valorizada pela etiqueta kamaiurá. Rejeitar uma oferta ou deixar de retribuir são atos antissociais que conduzem à animosidade e podem ocasionar o rompimento de relações.

$\mathrm{Na}$ esfera política, não há concentração de poder, embora algumas pessoas se destaquem pela capacidade de exercer algum tipo de controle e liderança dentro da comunidade. Os chefes de domicílios, os grandes pajés, os conhecedores 
da tradição, os especialistas no manuseio de ervas medicinais têm maior visibilidade social, e nos limites do seu campo específico de atuação exercem uma autoridade legítima. Eles também participam de um conselho mais amplo de homens, tradicionalmente denominado "roda dos fumantes", que se reúne para debater questões que afetam o conjunto da vida social e cujas decisões são tomadas por consenso. Assim, pode-se dizer que cada morador da aldeia tem em mãos uma pequena parcela de poder, incluindo as mulheres que fazem chegar sua opinião à "roda dos fumantes" pela voz do pai, do marido, do irmão ou do filho.

Há na comunidade diversos níveis de distinção social, e a mais visível é entre os descendentes de famílias de chefes, homens que ostentam o status hereditário de Morerekwat e mulheres Nuitu, e as pessoas comuns denominadas kamara. Na vida diária há pouca diferença entre eles, pois maior prestígio não acarreta privilégios materiais significativos e eventuais desníveis tendem a ser minorados pela redistribuição de bens, pela prática da dádiva. Mas é na esfera cerimonial que a diferença entre uns e outros se torna bastante visível, marcando a distância que os separa. Por ocasião da morte, por exemplo, apenas os morerekwat e as nuitu têm direito à realização do Kwaryp, os demais podem aproveitar a festa para homenagear seus mortos. Mas não havendo o falecimento de um morerekwat ou uma nuitu, não há possibilidade de ocorrer a cerimônia do Kwaryp.

A mitologia kamaiurá registra uma versão da criação dos humanos por Mavutsinin, na qual, após a transformação dos troncos de madeira em gente e em meio à alegria geral, os peixes deixaram a água e foram para a praia de Morená festejar o evento. A onça correu para lá e começou a lutar com os peixes. Mavutsinin transformou todos em índios kamara, fixando assim a diferença entre eles e as criaturas surgidas dos troncos, ligadas à sua própria linhagem (Villas Bôas, 2000, p.77-8). Por esse motivo, a festa do Kwaryp só ocorre quando do falecimento de descendentes de Mavutsinin, dizem os Kamaiurá. Na aldeia das almas, situada além da região de Morená, mantém-se a hierarquia entre os kamaras e os morerekwat e nuitu: as almas destes últimos se alimentam de boa comida, peixe e beiju, enquanto as outras, de grilo e barata, acreditando ser peixe, completam os narradores da aldeia.

Questões importantes da comunidade, discutidas e decididas na "roda dos fumantes", têm sua execução confiada ao morerekwat que ocupa o cargo de gestor da vida política ou chefe da aldeia, que é também seu representante diante dos outros povos e aldeias. ${ }^{4} \mathrm{O}$ cargo é hereditário e, até onde a memória dos mais velhos alcança, sua transmissão sempre foi alvo de contestação. Segundo eles, os grandes líderes do passado tinham uma prole grande, gerada por muitas esposas simultâneas ou sucessivas, o que ocasionava disputa dos descendentes ao cargo. É possível também que, em outros tempos, houvesse várias aldeias kamaiurá, e que a fusão em uma só tenha estimulado maior competição entre os morerekwat de diferentes famílias de chefes. Mas as tensões geradas pela com- 
petição são conduzidas com prudência e contornadas por um comportamento cauteloso, regulado e contido pelo interesse em manter alianças. São regras que impõem um relacionamento respeitoso e formalizado entre parentes afins e também entre os líderes, criando um importante escudo protetor, tanto nas relações cotidianas como nas cerimoniais.

Esse tipo de etiqueta organiza também as relações entre os diferentes povos que vivem na região do Alto Xingu, impedindo que aflorem as hostilidades que mutuamente alimentam. Outros recursos que ajudam a esvaziar as tensões intergrupais, já registrados por estudiosos, são as competições esportivas de arremesso de flechas entre competidores de povos diferentes, realizadas na cerimônia do Jawari, e a luta huka huka, que ocorre na etapa final do Kwaryp, entre lutadores de várias aldeias. Tanto a etiqueta como o esporte são assim mecanismos importantes que atuam na neutralização dos antagonismos nascidos do convívio social.

Antes de descrever os ritos envolvidos na festa do Kwaryp, é útil nomear suas diversas fases, cada qual instaurando sentimentos variados e exigindo dos protagonistas diferentes tipos de decisões:

A primeira fase tem início logo após o falecimento da pessoa e trata especialmente dos cuidados relativos ao corpo do morto e seu sepultamento.

A segunda fase ocorre várias semanas após a morte, quando os enlutados são instados a definir se desejam ou não o prosseguimento dos rituais. A decisão tem como ponto central a construção de uma cerca baixa de madeira (apenap) ao redor da sepultura e o consentimento significa que os enlutados concordam com a futura realização da festa do Kwaryp.

A terceira e última fase tem início quando as Plêiades podem ser vistas na linha do horizonte, anunciando tempo seco, dias quentes, noites frescas e águas propícias à pesca. Em algum momento dos meses de julho, agosto ou setembro intensificam-se os preparativos para a cerimônia do Kwaryp.

\section{Morte e sepultamento ${ }^{5}$}

Tão logo ocorra o falecimento de um morerekwat ou de uma nuitu, os homens se reúnem no centro da aldeia na "roda dos fumantes" para compor a equipe que irá cavar a sepultura e cuidar do corpo do morto. A adesão é voluntária e parentes próximos do morto não se candidatam. São seis homens de diferentes casas, exceto a do morto, que formam o grupo, sob a liderança de um deles. O primeiro contato com a família do morto é feito por esse líder, que pede permissão para fazer a sepultura. Via de regra, a permissão é negada no primeiro contato. A partir do momento em que a família resolve dar o consentimento, ela também escolhe um dos seus membros para ser o "dono do morto" (umanõjat), que desempenhará papel ativo nos rituais. ${ }^{6}$ Sua primeira função é comunicar a decisão familiar de permitir a abertura da cova ao líder e demais membros do grupo, que passam a ser chamados de "sepultadores" (ywywaraiokat). 
O modo de enterrar repete a forma como o pai do morto foi enterrado, sendo mais correntes as posições fetal (comumente denominada "sentado") e em pé, em que o corpo envolto na rede de dormir é atado a uma armação semelhante a uma escada e colocado na cova verticalmente. Para grandes chefes são abertas duas covas, ligadas por um túnel, sendo a rede de dormir que envolve o corpo atada aos postes fincados nas covas. $\mathrm{O}$ corpo não toca o chão. ${ }^{7}$

Todas as pessoas são enterradas no pátio da aldeia (também chamado centro), em frente ao tapyyp (casa das flautas ou casa dos homens). Não havendo mais espaço nessa área, a sepultura é aberta para os lados ou mais à frente. Em 2007 havia aproximadamente 50 pessoas enterradas no pátio. Natimortos e crianças com até sete anos são enterrados dentro da própria casa da família. Pessoa acusada de feitiçaria e executada na aldeia tem seu corpo largado na frente da casa da vítima do feitiço. O sepultamento é feito atrás da casa de seus parentes ou no mato, mesmo que se trate de pessoa de grande prestígio social, antes da acusação. Nada impede, entretanto, que o morto seja homenageado numa cerimônia do Kwaryp em outra aldeia.

Enquanto alguns "sepultadores" cuidam da abertura da sepultura, os demais vão pedir permissão para dar banho no morto, pintá-lo e adorná-lo. Se o morto for do sexo feminino, o procedimento é feito pelas esposas dos "sepultadores". Junto do corpo da mulher é colocado um fuso de fiar algodão, e no do homem, um arco e flechas. Em seguida, o corpo é coberto com esteiras, envolto na rede de dormir, que na sequência é costurada.

Depois de preparado o corpo, os "sepultadores" pedem ao "dono do morto" permissão para levá-lo para ser enterrado. Serão necessários vários pedidos até que o "dono do morto", transido de dor, concorde. O corpo é então carregado pela porta dos fundos, dá uma volta pelo lado esquerdo da casa e nela entra novamente; sai outra vez pela porta dos fundos, contorna a casa pelo lado direito e torna a entrar. Finalmente o cortejo dá uma volta no centro da casa e sai pela porta da frente em direção à sepultura, sempre acompanhado pelo canto do pajé. Contorna-se a sepultura e, em seguida, coloca-se o morto, com o rosto voltado para o nascente. O corpo é protegido com esteiras e na cabeça leva uma panela de cerâmica, trazida pelos familiares. Só então a sepultura é coberta com terra.

Os objetos enterrados com os mortos são imprescindíveis, uma vez que a alma precisa se proteger dos perigos que irão ameaçá-la quando ocorrer um eclipse lunar. Diz o mito que nessas ocasiões as almas enfrentam uma batalha com os pássaros, que as atacam com o intuito de tirar pedaços de suas cabeças para levar como alimento ao urubu-rei, seu chefe. Caso sejam atingidas, morrem definitivamente. Daí a panela cobrindo a cabeça do morto, o fuso para que as mulheres possam fazer armadilhas impedindo a aproximação dos agressores e 0 arco e flechas para permitir aos homens o ataque e a defesa.

Terminado o enterro, o líder dos "sepultadores" chama o "dono do morto" e seus familiares para que venham tomar o banho ritual sobre a sepultura, 
cuja finalidade é limpar as lágrimas. Durante três dias, a família enlutada faz uma pequena fogueira sobre a sepultura para ajudar a alma a encontrar o caminho para a aldeia das almas, sua última morada. À noite, um pajé procede ao ritual de expulsão da alma, sempre necessário, pois ela insiste em permanecer na casa onde sempre morou. Cheios de tristeza, os familiares enlutados podem permanecer mais de uma semana sem falar com ninguém, alimentando-se sobriamente. A aldeia como um todo silencia-se, cessam brincadeiras, jogos de futebol e qualquer atividade que revele alegria. A escola permanece fechada.

A vida ritual colabora para que o sofrimento comece a decrescer e, de certa forma, limita seu tempo de duração. Cerca de três semanas após o enterro, os "sepultadores" perguntam ao parente mais próximo do morto se a aldeia pode retomar seu ritmo usual. A dor da perda é avivada, chora-se muito, mas finalmente permite-se a volta do cotidiano. Já se ouvem risos, veem-se brincadeiras, fala-se mais naturalmente, embora não haja demonstração explícita de alegria, de felicidade. $\mathrm{O}$ reconhecimento à dor dos enlutados permanece, embora a comunidade retome com mais naturalidade as atividades corriqueiras. Com isso, o "sepultador" sente que já é hora de consultar o "dono do morto" sobre a oportunidade de fazer uma pescaria, que ele realizará com seus companheiros e outros homens da aldeia. Tão logo se defina o dia da pescaria, a família enlutada reúne forças para levantar jiraus e coletar lenha, pois os peixes capturados serão entregues ao "dono do morto" para que sejam assados e distribuídos a todos da aldeia.

O ritual que antecede a distribuição do alimento é realizado sobre a sepultura e consiste no corte de cabelo dos enlutados: nos homens ele é apenas aparado na nuca, e nas mulheres, ao longo de toda a cabeça. Segue-se o banho ritual desses familiares, acompanhado por cantos fúnebres. Após, os "sepultadores" pintam o cabelo dos homens com urucum, colocam em seus quadris uma faixa de fios de algodão e em cada orelha uma pena amarela. A seguir, o "dono do morto" e seus familiares lavam, pintam e colocam nos "sepultadores" adornos semelhantes aos que receberam. Finalmente, as demais pessoas da comunidade recebem também um banho sobre a sepultura, que lhes é dado pelas esposas dos "sepultadores" e pela esposa do "dono do morto", e em seguida são pintadas. Terminado o ritual, a família do "dono do morto" oferece àqueles que a pintaram penas de pássaros e outros adornos, como forma de retribuição. A comunidade faz chegar ao "dono do morto" e seus familiares recompensa semelhante pela pintura que recebeu, exercitando, ela também, o princípio da reciprocidade.

Essa sequência de rituais ajuda os enlutados a expressar sua dor e ameniza a aflição e a desorientação momentânea causada pelo impacto da morte. A comunidade como um todo esquece as rivalidades internas e compartilha do pesar, mantendo-se solidária à família atingida, o que torna a tristeza mais suportável. Vê-se com clareza que os mitos levam a comunidade a participar de modo solidário na delicada tarefa de afastar a dor causada pela morte, ao mesmo tempo que os ritos organizam os procedimentos da sua superação. 


\section{Construção do apenap}

"Com a lua nova no Oeste", como dizem, o líder dos "sepultadores" consulta seus companheiros sobre a oportunidade de propor ao "dono do morto" a colocação do apenap, que é uma cerca de pequenos troncos de madeira fincados ao redor da sepultura, e que lembra o formato de um retângulo com as duas linhas maiores curvadas para dentro. Se o "dono do morto" e seus familiares concordarem, é dado prosseguimento a um conjunto de providências que levará à futura realização da cerimônia do Kwaryp.

É uma decisão nem sempre fácil para a família do morto, pois, ao consentir a colocação do apenap, ela assume o pesado encargo de produzir e armazenar grande quantidade de polvilho, matéria-prima usada na elaboração do beiju, alimento que junto com peixe deverá ser fartamente distribuído aos convidados durante a cerimônia do Kwaryp.

Se o falecimento da pessoa coincidir com uma época de boa colheita de mandioca que, associada ao intenso trabalho das mulheres, permita acumulação significativa de massa de mandioca e polvilho, há a possibilidade de a família aceitar a construção do apenap. Mas há ainda outro fator a condicionar a decisão, a coleta do pequi. Para isso, é necessária uma grande quantidade da fruta, que amadurece no início da estação chuvosa (outubro), e de cujas sementes se extrai a castanha a ser distribuída aos chefes dos povos convidados. Se essas condições não puderem ser atendidas, os enlutados podem optar pelo adiamento do Kwaryp, pois, embora todos os mortos da categoria de morerekwat ou nuitu tenham direito à homenagem, não há regra que obrigue sua pronta realização.

Uma vez definida a construção do apenap, a comunidade expressa alegria e com júbilo os homens festejam a decisão no pátio da aldeia. O fato de estar assegurada a realização do Kwaryp instala um clima de expectativa otimista na aldeia. A partir de então, o "dono do morto" passa a ser denominado "dono da festa" (torypajat) ou simplesmente "dono" (jajat), e os "sepultadores", "donos da fala"(je'enjaret)), por terem sido responsáveis pelo discurso no qual solicitaram permissão para construir o apenap.

Após isso, o "dono da festa" procura as famílias de mortos kamaras, isto é, mortos que não pertenciam à categoria de morerekwat ou nuitu, convidandoas a prestar homenagem a eles. Como já foi dito, somente morerekwat e nuitu gozam do privilégio da cerimônia do Kwaryp, embora mortos comuns possam ser também reverenciados, ainda que em posição inferior. No Kwaryp de julho de 2007, os Kamaiurá homenagearam um morerekwat e uma criança de poucos meses, filha de um morerekwat, falecida há anos, e os Aweti aproveitaram a festa para render homenagem a dois mortos seus.

Os "donos da fala", com a ajuda de outros homens, partem para cortar a madeira a ser usada na construção do apenap, sempre com a permissão do "dono da festa", uma vez que esse deverá retribuir a tarefa fornecendo comida para os participantes. 
No dia seguinte, a madeira é solenemente levada para o pátio da aldeia, onde é cortada. As mulheres, impedidas de participar desse ritual, são finalmente autorizadas a assistir à fixação e amarração dos pedaços de tronco com embira.

Ao cair da tarde, o "dono da festa" se dirige para o apenap, levando consigo maracás e bastões que entrega a dois cantadores (maraka'ip), responsáveis pelos cantos rituais. Ao cessar o canto, os homens da aldeia, cuidadosamente pintados, se exibem na "dança do Kwaryp" (morahai) e junto com os cantadores recebem do "dono da festa" mingau de mandioca, peixe e beiju. Um pouco mais tarde, começam a soar as grandes flautas uruás, que serão tocadas por muitas horas. Finalmente, à noitinha, um grupo de mulheres lideradas pelos "donos da fala" percorre o pátio da aldeia cantando até entrar na casa do "dono da festa", de quem recebem peixe.

Pode-se ver que, nessa segunda etapa, é tecida uma mediação entre a dor causada pela perda de um membro da comunidade e a promessa de alegria, alimentada pela realização futura da festa do Kwaryp. Marco significativo dessa nova etapa é a substituição dos termos "dono do morto" e "sepultadores" por "dono da festa" e "donos da fala".

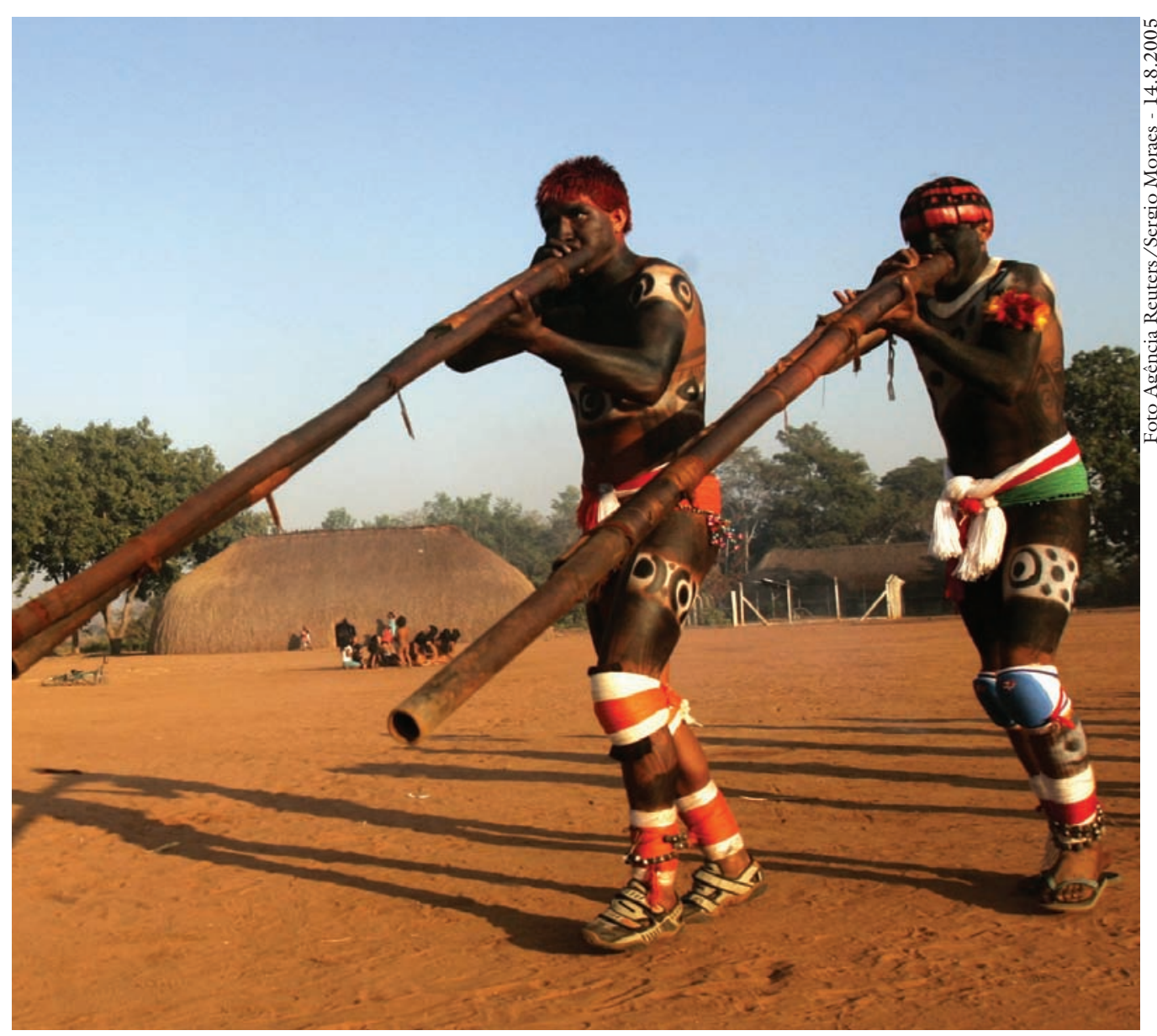

Tocadores das grandes flautas uruá. 


\section{A cerimônia do Kwaryp}

A grande festa do Kwaryp ocorre na estação seca, entre os meses de julho e setembro. São convidados para ela os povos do Alto Xingu com os quais os Kamaiurá têm boas relações no momento. As aldeias não incluídas no convite são as que em ocasiões anteriores exibiram um comportamento considerado inadequado. A disputa e a oposição política entre os alto-xinguanos fazem que a relação dos que serão convidados flutue de uma época para outra. Antigos adversários podem selar alianças no correr do tempo e ressentimentos podem afetar a relação entre aliados de outras épocas.

Uma vez definido o dia para a realização da festa, troncos de madeira são cortados para representar os mortos: os morerekwat terão troncos mais grossos, e os demais mortos, os ligeiramente mais finos. O apenap que cercava a sepultura do morerekwat é retirado do pátio e a madeira é posteriormente queimada.

À tarde, dois cantadores entoam os cantos no pátio, de costas para a casa das flautas (tapyyj), silenciando-se quando os homens chegam para exibir a "dança do Kwaryp". No dia seguinte, cantadores e dançarinos fazem outra demonstração.

Na manhã seguinte, é organizada uma grande pescaria (Kwary(p)apotap) com a participação de praticamente todos os homens da aldeia e algumas mulheres. Além dos pescadores, uma importante função é desempenhada pelos pajés, a quem cabe cuidar das rezas e dos rituais dirigidos aos espíritos das águas para que permitam o sucesso da empreitada.

Na pescaria do Kwaryp de 2007, o grupo acampou perto das lagoas Ywytatanip, Iratsimãi e Jenipavu, e logo iniciou os preparativos de cortar madeira para o jirau, muita lenha para moquear os peixes, além de montar uma barreira na boca da primeira lagoa. As grandes pescarias são realizadas nessas lagoas, que são de uso exclusivo dos Kamaiurá.

$\mathrm{Na}$ manhã seguinte, a rede é estendida na margem da lagoa e os pajés fumam e cantam ao seu lado, para em seguida espalharem sobre ela massa de mandioca. O ritual visa chamar os peixes. A rede é então estendida entre as duas margens. Os pajés fumam, para em seguida dar um mergulho nas águas. Saem com as mãos fechadas, seguem em direção à margem onde enterram, num ato simbólico, o ferrão da arraia. O ritual é necessário para que os pescadores não sejam feridos por ela.

Só então alguns homens puxam a rede até a barreira, enquanto outros entram na lagoa para bater o timbó. Assim que a rede é puxada, as mulheres aguardam na margem com bacias em que carregarão os peixes até o acampamento, onde serão limpos e moqueados.

No fim da tarde, os pajés vão para a margem da lagoa Iratsimãi, cada qual com uma pequena cabaça com mingau de pequi. Entram na água e jogam o mingau para o espírito da arraia, fincando em seguida uma vara no meio da lagoa, onde prendem as cabaças vazias. De volta à margem, fumam novamente. 
À noite, os rapazes chamuscam as pernas com folhas de palmeira pinop em chamas e, em seguida, esfregam nas pernas a folha da planta curana'i. O chá dessa planta é usado pelas mulheres para diminuir a menstruação, e seu uso durante a pescaria visa proteger a perna de eventuais ferimentos causados por arraia. Os rapazes submeteram-se ao ritual por terem apanhado pouco peixe durante o dia. O pajé consultou o espírito do peixe e soube que na aldeia uma mulher Kamaiurá estevava menstruada e o cheiro do sangue passou para os pescadores que residiam na mesma casa. Para revelar seu descontentamento, Pira'i, mãe do peixe, fez um furo na rede.

Na manhã seguinte, os pajés repetiram o ritual de enterrar o ferrão da arraia, na Lagoa Iratsimãi, e a captura de peixe foi bastante boa. A abundância de peixe permite uma distribuição generosa de alimento e garante que o Kwaryp ganhe destaque na avaliação da melhor festa de temporada, tema constante de comentários na área. Em setembro de 2003, os Iawalapiti realizaram o Kwaryp em homenagem a Orlando Villas Bôas, um dos maiores já visto. Eram muitos os convidados de fora, parentes, amigos e jornalistas. No Posto Leonardo e na própria aldeia, havia muitas aeronaves estacionadas. Durante a festa, o movimento foi grande e a homenagem ao prestigioso indigenista emocionou os presentes.

No ano seguinte, os Kamaiurá promoveram o Kwaryp de um morerekwat, convidando ao mesmo tempo os familiares de Roberto Marinho para a homenagem que prestariam ao dono da TV Globo. Repetiu-se o mesmo movimento de convidados e aeronaves. Os comentários sobre qual teria sido a festa mais bonita alimentaram por bom tempo as conversas no Alto Xingu.

Com a volta dos pescadores à aldeia, inicia-se outra importante sequência de rituais. Na parte da manhã, os enlutados são levados ao pátio para que tomem o banho destinado a retirar o luto. No dia seguinte, são enviados os emissários portadores do convite formal (pareat) às aldeias participantes. Com a facilidade do transporte em caminhão, os pareat, que em outras épocas partiam com muitos dias de antecedência, agora podem fazê-lo na véspera da festa.

No dia seguinte, são cavados os buracos onde serão colocados os troncos, defronte a casa das flautas. À colocação e à pintura dos troncos seguem-se os cantos do maraka'ip, após o que os familiares enlutados se dirigem ao pátio para chorar a morte do parente e adornar o poste que o representa com cintos, cocares, colares etc. O término da sessão é indicado por dois tocadores da flauta uruá que saem da casa do dono da festa, circundam o pátio e a ela retornam.

Depois de montada uma cobertura para proteger os troncos, tem início a pintura dos enlutados pelos parentes dos pareat. Sob essa cobertura e junto aos troncos, os parentes ficarão lamentando e chorando a noite toda, muitas vezes com ajuda de carpideiras.

Para a maior parte da aldeia, é hora de procurar terminar os enfeites, caprichar nas pinturas corporais, cuidar da aparência. Os rapazes, que durante o ano se exercitaram na luta huka huka, aguardam o grande momento que irá consa- 


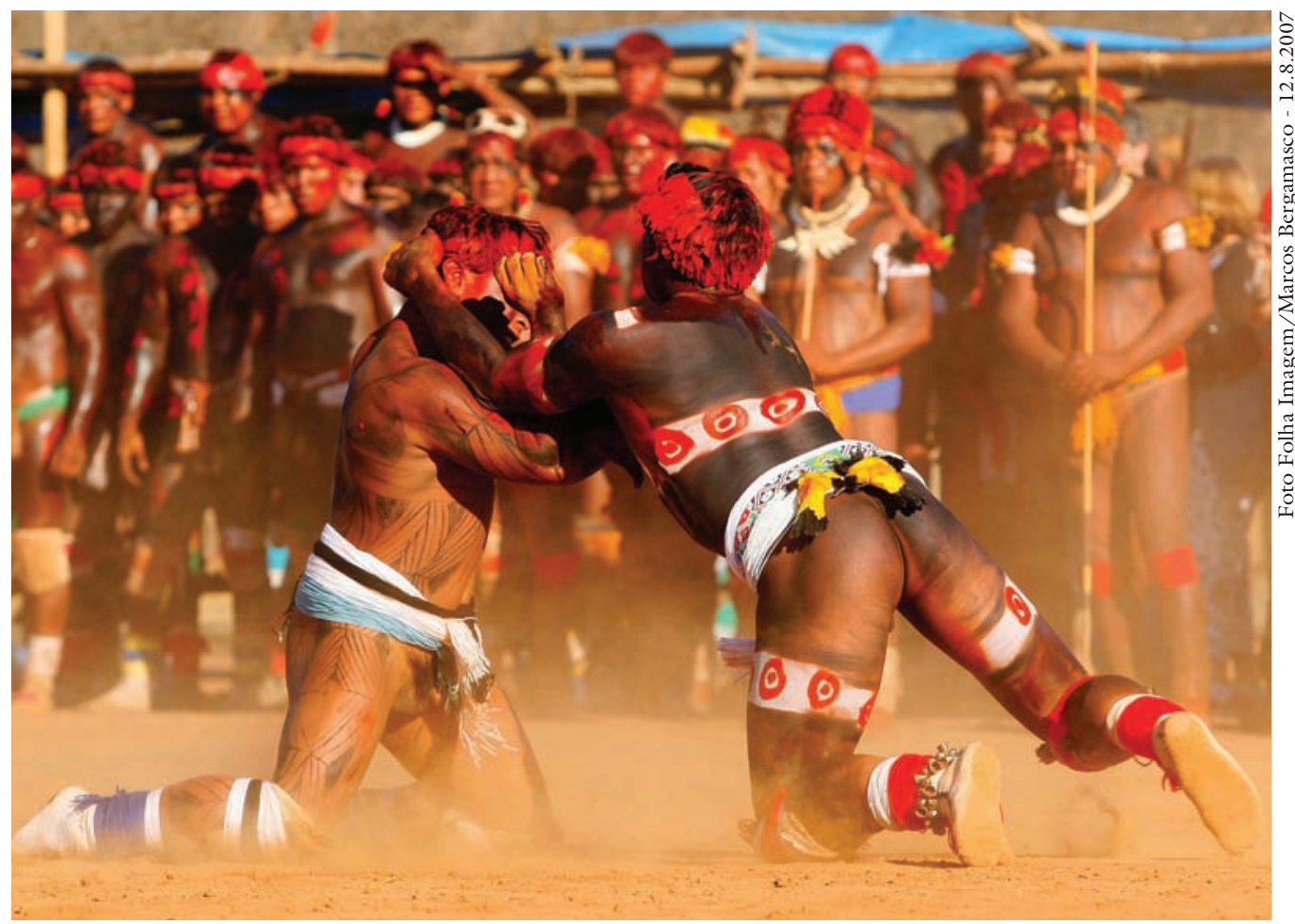

A luta huka huka é considerada o ponto alto do Kwaryp.

grar os campeões. É uma ocasião única na qual eles podem vir a ganhar enorme prestígio na região, na aldeia e, especialmente, junto às mulheres. Usam o jajap, pequeno triângulo de cabaça com dentes de peixe-cachorra incrustados, para escarificar braços e pernas e ganhar maior vigor. Ingerem chás de ervas para aumentar a força, e ganham ainda mais confiança no seu desempenho após o pajé rezar junto a eles para assegurar-lhes vitória nos diversos embates que travarão. Em meio aos cantos entoados pelos maraka'ip que se intercalam com a "dança do Kwaryp", a aldeia é invadida pelo burburinho das providências.

O embate no huka huka é o ponto alto do Kwaryp, e, para a maioria das pessoas, o seu principal foco de interesse, com a possível exceção dos familiares mais próximos da pessoa falecida. A luta oferece oportunidade ímpar para que os diferentes povos explicitem suas hostilidades latentes num encontro que, embora agressivo, é conduzido segundo regras estritas.

No final da tarde, começam a chegar as pessoas das aldeias convidadas: param cerca de 200 metros da entrada da aldeia onde são recebidos pelo pareat que lhes entregou o convite da festa. Depois da cerimônia de recepção, são conduzidas para um local no mato, previamente limpo e preparado pelo pareat, onde irão armar seu acampamento. Mais à noite, o pareat vem até o acampamento para conduzir os líderes até a aldeia e acomodá-los em bancos colocados à pequena distância dos troncos e das sepulturas, onde mais uma vez lhes é oferecido alimento. Os homens kamaiurá vêm ao pátio para uma execução da dança ho’at 
(termo que designa "grupo reunido", “coeso"), com grande alarido circundam os chefes e os troncos, entoam em uníssono um grito que poderia ser designado marcial (que guarda semelhança ao "hip hip hurra" das torcidas esportivas) e em seguida se dispersam. A dança ho’at indica a direção dominante que anima a festa a partir de então. Os homens exibem sua força e entusiasmo guerreiro, em que a violência de algum modo é controlada pelo ritual. Mas a exibição do ho'at se aproxima claramente de um grito de guerra. Os lutadores da aldeia visitante entram no pátio e repetem o mesmo circuito ritual na dança ho'at, pegam achas de lenha que alimentam as fogueiras colocadas diante dos troncos e retornam ao acampamento. Pouco depois seus chefes igualmente se retiram. O mesmo ritual e a mesma coreografia são repetidos por cada um dos grupos convidados.

Mais tarde, iniciam-se os cantos dos maraka'ip kamaiurá. Vêm depois os maraka'ip de uma das aldeias convidadas e, assim, aos pares, se apresentam os cantadores de todos os visitantes, recebendo ao final peixe e beiju dos anfitriões. Enquanto os maraka'ip cantam e os familiares dos mortos choram ao redor do tronco do parente homenageado, pajés e rezadores ficam atentos aos movimentos dos visitantes e vasculham diversos locais da aldeia. Do mesmo modo que pajés kamaiurá entram em transe durante a pescaria para verificar se alguma aldeia vizinha colocou feitiço nas águas da lagoa para afugentar os peixes, no Kwaryp, durante boa parte do tempo em que os convidados permanecem nas cercanias da aldeia e mesmo no pátio, os pajés procuram identificar feitiços deixados junto à casa das flautas ou pelos caminhos com o intuito de atingir os lutadores locais, fazendo-os fracassar na luta. São muitos os procedimentos mágicos destinados a prejudicar o bom desempenho dos lutadores. No próprio acampamento, os visitantes têm a cautela de cheirar a comida oferecida a fim de detectar cheiro de tabaco, indício de que foi "rezada", isto é, alvo da ação das rezas (monaré orepeiu) dos pajés locais.

A desconfiança recíproca entre convivas e anfitriões é uma constante nas cerimônias e contrasta vivamente com a generosidade da acolhida e a formalidade do comportamento de uns e outros.

Pouco antes do amanhecer, os parentes enlutados recolhem-se para descansar, pois sabem que a alma do morto, que até então permaneceu no tronco, também segue seu caminho com o raiar do Sol. Nessa noite, praticamente ninguém consegue dormir. Alimento é levado várias vezes aos acampamentos pelos respectivos pareat, onde é grande o alvoroço, pois como os lutadores não podem dormir, temendo os augúrios dos sonhos, as pessoas conversam, brincam e cantam. Vez por outra, um lutador visitante zomba, em altos brados, de algum adversário dos acampamentos vizinhos ou da aldeia. Ocorrem verdadeiros duelos de pilhérias, de lado a lado, tentando-se afastar a ameaça do sono. O clima de euforia e muita comilança se prolonga até o amanhecer.

Logo cedo, na manhã seguinte, os visitantes são conduzidos até a aldeia pelos pareat. Aos chefes são reservados bancos, e cada grupo, com toda sua 
bagagem, se acomoda atrás deles em espaços previamente definidos. As flautas uruá são tocadas e os homens kamaiurá dão uma volta no pátio dançando o ho'at, o mesmo acontecendo com os homens dos grupos visitantes que, um a um, se apresentam para em seguida se postarem atrás dos seus chefes.

O "dono da festa" passa a chamar os melhores lutadores kamaiurá, que seguem até o meio do pátio e, de joelhos e mãos no chão, olham em direção ao povo desafiado. Os adversários são convocados pelo seu chefe e colocam-se na mesma posição, a uma pequena distância dos lutadores que os esperam. Tem início o embate, uma espécie de luta livre, cujo vencedor é aquele que consegue derrubar o adversário, segurando-o por detrás dos joelhos. Raramente a queda de um lutador é registrada, pois basta que seu opositor lhe toque a região traseira dos joelhos para o embate se encerrar. Entre grandes lutadores, esse é o comportamento adequado e apenas jovens iniciantes chegam a provocar a queda do adversário, no que são publicamente censurados. Terminada a luta entre os melhores lutadores, os demais homens dos dois lados se enfrentam, sem nenhuma outra formalidade. $\mathrm{O}$ mesmo procedimento se repete com relação a cada um dos demais grupos visitantes que, um por vez, enfrentam seus anfitriões; numa primeira rodada os grandes lutadores são convocados e a seguir os demais.

No Kwaryp de julho de 2007, dois lutadores kalapalo desmaiaram durante a luta e outros dois saíram carregados, chorando de modo convulsivo. Alegaram que passaram mal em virtude de algum feitiço. $\mathrm{O}$ desmaio teria sido provocado por uma espécie de choque que receberam. Segundo os Kamaiurá, esse é o recurso usado por adversários quando sentem que vão perder a luta.

Antes de a festa se encerrar, e depois de tocadores visitantes se exibirem com suas flautas uruá, tem início o ritual de distribuição da castanha do pequi. Uma jovem kamaiurá que está em reclusão pubertária é trazida ao pátio e recebe do "dono da festa" uma pequena cuia com castanhas. Em companhia do "dono da festa", ela se dirige a um dos chefes visitantes e coloca as castanhas junto a seus pés. Em seguida, o chefe visitante retira dos joelhos da jovem o cinto de algodão que ela porta. Outro cinto é colocado na jovem por sua mãe e ela faz a distribuição de castanha a cada um dos chefes convidados. Na aldeia de cada visitante, a castanha recolhida será misturada ao pirão de peixe, distribuído para os moradores.

Terminada a festa, muitos visitantes seguem até as casas levando bens para serem trocados. É o moitará entre famílias que tem lugar no final do Kwaryp. Quando todos já se foram, os troncos são retirados dos buracos e colocados no chão até que resolvam levá-los, sem formalidade, para as águas da lagoa.

Num balanço final, vê-se que a cerimônia destinada a reverenciar os mortos ajuda também os que ainda vivem: diminui as tensões locais e desperta o sentimento de unidade na aldeia, que vibra durante a luta. No plano externo, reafirma os vínculos entre os povos, mesmo que em meio a ambiguidades: todos são acolhidos com respeito e generosidade, ao mesmo tempo que travam uma batalha silenciosa em que os guerreiros são pajés e espíritos. 
Aos poucos a vida na aldeia retoma o ritmo usual. Durante um bom tempo as conversas giram em torno da festa, dos convidados, da luta e dos novos campeões: comentários, acusações, elogios, críticas e mexericos. Dos velhos que morreram guardarão lembranças e os nomes, que serão transmitidos à geração seguinte. Possivelmente, viúvos e viúvas voltam a pensar em novo casamento, casais planejam o nascimento de outro filho. As roças continuam a ser plantadas à espera das chuvas e, caso algum morerekwat ou nuitu venha a falecer, todos ficam atentos ao pequi, que ficará maduro no final de outubro.

Notas

1 Eduardo Galvão (1979 ) fez uma análise abrangente de diferentes aspectos da cultura alto-xinguana, com dados coletados em 1947 e 1950, em que destaca a ampla difusão de práticas compartilhadas.

2 Estudo pioneiro, e bastante completo, sobre o Kwaryp foi realizado por Pedro Agostinho (1974), com dados coletados em 1965, 1966 e 1969.

3 Lucy Seki (2000) registra que o termo -owajat, usado pelo pai ou mãe do ego para referir-se ao pai ou mãe do cônjuge do ego, pode ser traduzido também como "inimigo".

4 Agradecemos imensamente ao professor Aryon Rodrigues a pronta informação sobre o termo morerekwat: "sua base é o verbo $-k o \sim$ - eko 'estar em movimento, estar vivo, viver', com o prefixo causativo comitativo $e r$ - que significa mandar alguém fazer algo em companhia de quem manda -er-eko 'fazer alguém viver em sua companhia, fazer alguém viver consigo'; a essa forma vai prefixado o morfema poro que significa genericamente 'coletividade' (e que perde sua última vogal diante da vogal inicial do verbo): por-er-eko 'fazer muitos vierem consigo'; deste verbo é derivado um nome de agente com o sufixo - at, diante do qual a vogal $o$ do verbo fica assilábica, isso é w: por-er-er-ekw-at 'o que/ aquele que faz muitos viverem consigo'; por fim, o prefixo relacional $m$ - que se associa aos temas começados por $p$ para indicar relação com seres humanos (e foneticamente funde-se com o $p$ ): morerekwat 'o que faz a gente/o povo viver consigo'”.

5 Os dados referentes a morte e sepultamento foram fornecidos por informantes Kamaiurá Takumã, Kotok Menyúautát, Mapulu, Awirinapu Akain (Raul), Kanawayuri (Marcello), Maiarú (Katão) e Uaiukumã (Kaceli), uma vez que não tivemos oportunidade de presenciar tais eventos durante a pesquisa de campo.

6 O Kwaryp é a única cerimônia que tem mudança de dono, que é usualmente um parente do morto. As demais cerimônias têm dono fixo, status transmitido hereditariamente.

7 Kalervo Oberg (1956, p.68) afirma que o tipo de enterramento depende do status da pessoa: quem não tem ascendência kamaiurá pura é colocado horizontalmente na cova; filhos adultos de chefes, sentados; kamaiurá puro, em pé; e grandes chefes, na rede suspensa.

Referências bibliográficas

AGOSTINHO, P. Kwarip, mito e ritual no Alto Xingu. São Paulo: EPU, 1974.

GALVÃO, E. Apontamentos sobre os índios Kamaiurá. In: GALVÃO, E. Encontro de sociedades: índios e brancos no Brasil. Rio de Janeiro: Paz e Terra, 1979a. p.17-38. 
GALVÃO, E. O uso do propulsor entre as tribos do Alto Xingu. In: Encontro de sociedades: índios e brancos no Brasil. Rio de Janeiro: Paz e Terra, 1979b. p.39-56.

. Cultura e sistema de parentesco das tribos do Alto Rio Xingu. In: Encontro de sociedades: índios e brancos no Brasil. Rio de Janeiro: Paz e Terra, 1979c. p.73-119. OBERG, K. Indians tribes of northern Mato Grosso. Washington: Smithsonian Institucion - Institute of Social Anthropology, 1956. (Publication n.15).

SCHADEN, E. Aspectos e problemas etnológicos de uma área de aculturação intertribal: o Alto Xingu. In: Aculturação indigena. Ensaio sobre fatores e tendências da mudança cultural de tribos índias em contacto com o mundo dos brancos. São Paulo, 1964. p.65-102. Tese apresentada ao concurso para a Cadeira de Antropologia da Faculdade de Filosofia, Ciências e Letras, Universidade de São Paulo.

SEKI, L. Gramática do Kamaiurá. Campinas: Editora da Unicamp, 2000.

VILLAS BÔAS, O. Kuarup. A lenda da criação. In: $A$ arte dos pajés. São Paulo: Globo, 2000. p.77-8.

RESUMO - O objetivo deste ensaio é descrever a cerimônia do Kwaryp, ocasião cerimonial única que reúne a maioria dos povos da região em uma aldeia anfitriã, e focalizar os principais procedimentos envolvidos na realização da festa, destacando as práticas voltadas tanto para reafirmar a coesão social como para expressar a ambiguidade das relações entre as diferentes aldeias. Solidariedade e hostilidade se alternam na configuração do universo alto-xinguano e revelam a complexa rede política que o envolve.

PALAVRAS-CHAVE: Cerimônia Kwaryp, Ambiguidade das relações, Unidade alto-xinguana, Coesão social.

ABSTRACT - This paper aims to describe the ritual of Kwaryp, an unique ceremonial occasion, which assembles the majority of the inhabitants of the region in a hostess village. It also intends to focus the main proceedings envolved in the accomplishment of the feast, appraising the practices aimed to reaffirm the social cohesion as well to express the ambivalence of the relations established between different villages. Solidarity and hostility alternate in the conformation of the universe of upper Xingu and reveal the complex political network in which that universe is embbeded.

KEYWORDS: Kwaryp ritual, Ambiguity of relations, Unity of Upper Xingu, Social cohesion.

Carmen Junqueira é professora emérita da PUC-SP, professora titular do Departamento de Antropologia e do Programa de Estudos Pós-Graduados em Ciências Sociais da PUC-SP. @-carmen.junqueira@terra.com.br

Vaneska Taciana Vitti é antropóloga, mestre em Ciências Sociais-Antropologia pela PUC-SP e pesquisadora do Núcleo de Etnologia, Meio Ambiente e Populações Tradicionais (Nema) da PUC-SP. Atualmente trabalha no Projeto Xingu Unifesp/EPM. $@$ - tacianavitti@gmail.com

Recebido em 20.10.2008 e aceito em 15.11.2008. 